Article

\title{
Ga-Substituted Cobalt-Chromium Spinels as Ceramic Pigments Produced by Sol-Gel Synthesis
}

\author{
Egle Grazenaite 1,2, Edita Garskaite ${ }^{3}{ }^{-}$, Zivile Stankeviciute ${ }^{2}$, Eva Raudonyte-Svirbutaviciene ${ }^{4}$, \\ Aleksej Zarkov ${ }^{2}$ (D) and Aivaras Kareiva ${ }^{2, *(1)}$ \\ 1 Department of Detailed Research, Cultural Heritage Centre, Asmenos 10, 01135 Vilnius, Lithuania; \\ eglolis@gmail.com \\ 2 Institute of Chemistry, Vilnius University, Naugarduko 24, 03225 Vilnius, Lithuania; \\ zivile.stankeviciute@chf.vu.lt (Z.S.); aleksej.zarkov@chf.vu.lt (A.Z.) \\ 3 Wood Science and Engineering, Department of Engineering Sciences and Mathematics, \\ Luleå University of Technology, Forskargatan 1, 93187 Skellefteå, Sweden; edita.garskaite@ltu.se \\ 4 SRI Nature Research Centre, Institute of Geology and Geography, Akademijos 2, 08412 Vilnius, Lithuania; \\ eva.raudonyte@gmail.com \\ * Correspondence: aivaras.kareiva@chgf.vu.lt
}

Received: 27 October 2020; Accepted: 24 November 2020; Published: 25 November 2020

\begin{abstract}
For the first time to the best of our knowledge, cobalt-chromium spinels $\mathrm{CoCr}_{2-\mathrm{x}} \mathrm{Ga}_{\mathrm{x}} \mathrm{O}_{4}$ with different amounts of gallium ( $x=0-2$ with a step of 0.5 ) were synthesized via the aqueous sol-gel route as ceramic pigments. The phase composition, crystallite size, morphological features, and color parameters of new compositions and their corresponding ceramic glazes were investigated using XRD, CIELab, SEM, and optical microscopy. It was demonstrated that the formation of single-phase $\mathrm{CoCr}_{2-\mathrm{x}} \mathrm{Ga}_{\mathrm{x}} \mathrm{O}_{4}$ samples was problematic. Full substitution of $\mathrm{Cr}^{3+}$ by $\mathrm{Ga}^{3+}$ ion in the spinel resulted in the formation of light blue powders, which yielded violetish blue color for the corresponding ceramic glaze.
\end{abstract}

Keywords: sol-gel processing; cobalt chromite; mixed-metal oxides; gallium substitution; ceramic pigments

\section{Introduction}

Different metal oxides and mixed metal oxides are known to serve as ceramic pigments. For various applications, pigments have specific requirements such as chemical and thermal stability, particle size, hiding and tinting power, etc. Spinels which are mixed-metal oxides with a general formula of $\mathrm{AB}_{2} \mathrm{O}_{4}$ are very attractive in the pigmentary field due to their characteristics of high mechanical resistance, and high thermal and chemical stability [1,2]. The nature of tetrahedral or octahedral cations in spinel structure and the potential of different types of doping give diversity in colors and properties. Cobalt chromite $\left(\mathrm{CoCr}_{2} \mathrm{O}_{4}\right)$ pigments are well known and have been synthesized using sol-gel [3-5], combustion [6-8], combined sol-gel combustion [9], solid-state reaction [10], microwave-assisted [11], and spray pyrolysis [12] methods. In our previous studies, cobalt chromite based compounds $\mathrm{Co}_{1-\mathrm{x}} \mathrm{M}_{\mathrm{x}} \mathrm{Cr}_{2} \mathrm{O}_{4}(\mathrm{M}=\mathrm{Ni}, \mathrm{Cu}$, and $\mathrm{Zn})$ with different transition metal concentrations $\left(0 \leq x \leq 1\right.$ with a step of 0.25) [13] and $\mathrm{CoCr}_{2-\mathrm{x}} \mathrm{Ln}_{\mathrm{x}} \mathrm{O}_{4}\left(\mathrm{Ln}=\mathrm{Tm}^{3+}\right.$ and $\left.\mathrm{Yb}^{3+}\right)$ pigments with different substitutional levels of lanthanide $(x=0-0.5)$ [14] have been synthesized using an aqueous sol-gel synthetic approach and characterized by various techniques.

Gallium-containing spinels attracted the interest of scientists for many decades. Such compounds were synthesized and investigated mainly for conducting luminescence and other properties. $\mathrm{CdGa}_{2} \mathrm{O}_{4}$ spinel was found to be a promising compound as a transparent electronic conductor [15], 
whereas $\mathrm{ZnGa}_{2} \mathrm{O}_{4}$ is a great UV-transparent electronic conductor [16]. $\mathrm{MgGa}_{2} \mathrm{O}_{4}$ doped by $\mathrm{Cr}^{3+}$ ion [17] and $\mathrm{Si}^{4+}$ ion co-doped $\mathrm{MgGa}_{2} \mathrm{O}_{4}: \mathrm{Cr}^{3+}$ [18] were prepared and investigated as phosphors. $\mathrm{CuGa}_{2} \mathrm{O}_{4}$ nanocrystalline powders were synthesized and investigated as sensors for $\mathrm{H}_{2}$, liquefied petroleum gas, and $\mathrm{NH}_{3}$ [19]. Moreover, $\mathrm{NiGa}_{2} \mathrm{O}_{4}$ thin films doped with different levels of $\mathrm{Eu}^{3+}$ ion were prepared and their luminescent properties were characterized [20]. However, there are no records of the research preparing gallium-containing spinels as ceramic pigments, to the best of our knowledge. In general, the number of reports of the research of any gallium-containing structures as ceramic pigments is relatively low. Lutetium gallium garnets co-doped with chromium and calcium $\left(\mathrm{Ca}_{x} \mathrm{Cr}_{x} \mathrm{Lu}_{3-2 x} \mathrm{Ga}_{5} \mathrm{O}_{12}\right.$ up to $\left.\mathrm{x}=0.2\right)$ were obtained by solid-state reaction as pink ceramic pigments [21,22]. In another study, the investigated gallium gadolinium garnet $\left(\mathrm{Gd}_{3} \mathrm{Ga}_{5} \mathrm{O}_{12}\right)$ doped with $\mathrm{Cr}^{4+}$ resulted in green shades of ceramic glazes due to reduction of $\mathrm{Cr}^{4+}$ to $\mathrm{Cr}^{3+}$ that dissolved in the glaze [23]. Perovskite-like purple inorganic pigments $\mathrm{YGa}_{1-\mathrm{x}} \mathrm{Mn}_{\mathrm{x}} \mathrm{O}_{3}(0<\mathrm{x} \leq 0.10)$ were prepared by a sol-gel technique [24].

In this study, $\mathrm{Ga}^{3+}$ was chosen as a substitutional ion for the modification of cobalt chromite by replacing $\mathrm{Cr}^{3+}$ ion. Therefore, cobalt-chromium spinels as ceramic pigments $\mathrm{CoCr}_{2-x} \mathrm{Ga}_{x} \mathrm{O}_{4}$ with different substitutional levels of gallium $(x=0-2$ with a step of 0.5$)$ were synthesized using the aqueous sol-gel method. The phase purity, morphological properties, and color parameters of new $\mathrm{CoCr}_{2-\mathrm{x}} \mathrm{Ga}_{\mathrm{x}} \mathrm{O}_{4}$ ceramic pigments were investigated in this study.

\section{Materials and Methods}

\subsection{Materials}

All purchased reagents were used as received without further purification. Aqueous sol-gel synthesis [16] was carried out using $\mathrm{Cr}\left(\mathrm{NO}_{3}\right)_{3} \cdot 9 \mathrm{H}_{2} \mathrm{O}$ (99.0\%, Sigma-Aldrich, Darmstadt, Germany), $\mathrm{Co}\left(\mathrm{NO}_{3}\right)_{2} \cdot 6 \mathrm{H}_{2} \mathrm{O}\left(97.7 \%\right.$, Alfa Aesar, Kandel, Germany), $\mathrm{Ga}_{2} \mathrm{O}_{3}$ (99.99\%, Alfa Aesar, Kandel, Germany), $\mathrm{HNO}_{3}\left(67 \%\right.$, Eurochemicals, Vilnius, Lithuania) and 1,2-ethanediol $\mathrm{C}_{2} \mathrm{H}_{6} \mathrm{O}_{2}(99.5 \%$, Sigma-Aldrich, Darmstadt, Germany) as starting materials for the preparation of precursor gels. For the formation of ceramic glazes, the Czech transparent colorless base glaze (Ferro, Frankfurt/Main, Germany) was used.

\subsection{Aqueous Sol-Gel Synthesis}

For the synthesis of Co-Cr-O precursor gel, stoichiometric amounts of $\mathrm{Co}\left(\mathrm{NO}_{3}\right)_{2} \cdot 6 \mathrm{H}_{2} \mathrm{O}$ and $\mathrm{Cr}\left(\mathrm{NO}_{3}\right)_{3} \cdot 9 \mathrm{H}_{2} \mathrm{O}$ were dissolved in deionized water and mixed together [4]. For the synthesis of Co-Cr-Ga-O precursor gel, the appropriate amount of $\mathrm{Ga}_{2} \mathrm{O}_{3}$ was dissolved in diluted hot nitric acid first and then mixed with aqueous solutions of $\mathrm{Co}\left(\mathrm{NO}_{3}\right)_{2} \cdot 6 \mathrm{H}_{2} \mathrm{O}$ and $\mathrm{Cr}\left(\mathrm{NO}_{3}\right)_{3} \cdot 9 \mathrm{H}_{2} \mathrm{O}$. After mixing, the solutions were stirred at $40-50{ }^{\circ} \mathrm{C}$ for $20 \mathrm{~min}$ and then $2 \mathrm{~mL}$ of 1,2-ethanediol was added with continuous stirring at the same temperature for $1 \mathrm{~h}$. The solutions were concentrated by continuous stirring and evaporation at $60-70^{\circ} \mathrm{C}$. Prepared gels were dried in a furnace at $105-110^{\circ} \mathrm{C}$ in air, carefully ground in an agate mortar, and annealed at $700^{\circ} \mathrm{C}$ in the air for $3 \mathrm{~h}$ with a heating rate of $5{ }^{\circ} \mathrm{C} / \mathrm{min}$. The obtained powders were ground once again and additionally heated at $1000^{\circ} \mathrm{C}$ in the air for $5 \mathrm{~h}$ with a heating rate of $10^{\circ} \mathrm{C} / \mathrm{min}$.

\subsection{Preparation of Ceramic Glazes}

The obtained pigments were used for the preparation of ceramic glazes. For that purpose, $0.05 \mathrm{~g}$ ( $5 \mathrm{wt} \%$ ) of each pigment was mixed with $0.95 \mathrm{~g}$ of the Czech base glaze powders and a little bit of water and carefully plastered onto terracotta tiles $(0.03 \times 0.04 \mathrm{~m})$. After drying in air, the prepared terracotta samples were fired in an oxidizing atmosphere in an electric furnace at $1000^{\circ} \mathrm{C}$ for $1 \mathrm{~h}$ with a heating rate of $5^{\circ} \mathrm{C} / \mathrm{min}$. 


\subsection{Characterization}

For the identification of the phase composition of the resulted products, the powder X-ray diffraction (XRD) analysis was used. The measurements were performed using a Rigaku MiniFlex II diffractometer (The Woodlands, TX, USA), operated at $30 \mathrm{kV}$ and $10 \mathrm{~mA}$ with a scanning speed of $10 \% \mathrm{~min}$, in a scanning range of $2 \theta=10-80^{\circ}$, using $\mathrm{Cu} \mathrm{K} \alpha$ radiation $(\lambda=1.540562 \AA)$. The obtained diffraction data were refined by the Rietveld method using the FullProf suite. The tentative crystallite sizes were determined by the Scherrer equation:

$$
\tau=0.9 \lambda / B \cos \theta
$$

where $\tau$ is the mean crystallite size, $\lambda$ is the $\mathrm{X}$-ray wavelength, $B$ is the line broadening at half maximum intensity (FWHM) (in radians) and $\theta$ is the Bragg angle. The color of the pigments and the ceramic glazes was evaluated by the CIELab colorimetric method, which is recommended by the Commission Internationale de $\mathrm{l}^{\prime}$ Eclairage. The $\mathrm{L}^{*}, \mathrm{a}^{*}$, and $\mathrm{b}^{*}$ parameters were measured on a Perkin Elmer Lambda 950 spectrophotometer (Waltham, MA, USA) in the 780-380 nm range, employing an illuminant D65 and a $10^{\circ}$ standard observer. In the CIELab system, the coordinate $\mathrm{L}^{*}$ represents the lightness of the color $\left(\mathrm{L}^{*}=0\right.$ and $\mathrm{L}^{*}=100$ represents black and white, respectively). The negative/positive values of coordinate $a^{*}$ represent green/red hue, respectively, and the parameter $b^{*}$ corresponds to blue/yellow hue, where negative values are for blue and positive for yellow. The morphological features of obtained samples were investigated using a scanning electron microscope (SEM) (Hitach SU70, Tokyo, Japan). Quantification of Co, Cr, and Ga in synthesized specimens was performed by inductively coupled plasma optical emission spectrometry (ICP-OES) using Perkin-Elmer Optima 7000 DV spectrometer (Waltham, MA, USA). Sample decomposition procedure was carried out in concentrated nitric acid $\left(\mathrm{HNO}_{3}\right.$, Rotipuran ${ }^{\circledR}$ Supra 69\%, Roth) using microwave reaction system Anton Paar Multiwave 3000 (Graz, Austria) equipped with XF100 rotor and PTFE liners. The following program was used for the dissolution of powders: during the first step, microwave power was linearly increased to $800 \mathrm{~W}$ in $15 \mathrm{~min}$ and held at this point for the next $20 \mathrm{~min}$. Once the vessels have been fully cooled and depressurized the obtained clear solutions were quantitatively transferred into volumetric flasks of a certain volume and diluted with deionized water. Calibration solutions were prepared by an appropriate dilution of the stock standard solutions (single-element ICP standards 1000 mg/L, Roth).

\section{Results and Discussion}

The XRD patterns of Ga-doped $\mathrm{CoCr}_{2-x} \mathrm{Ga}_{x} \mathrm{O}_{4}(\mathrm{x}=0-2$ with a step of 0.5$)$ samples, depending on the substitution ratio and heating temperature, are given in Figure 1. The main crystalline phase of the synthesis products obtained at $700{ }^{\circ} \mathrm{C}$ was a solid solution of cubic $\mathrm{CoCr}_{2} \mathrm{O}_{4}(\mathrm{PDF} 22-1084)$ and $\mathrm{CoGa}_{2} \mathrm{O}_{4}$ spinels (PDF 11-0698). However, an additional $\mathrm{Cr}_{2} \mathrm{O}_{3}$ phase (PDF 38-1479) was observed for the sample with $\mathrm{x}=0.5$. Phase composition analysis revealed that chromium substitution by gallium was not successful at a higher temperature. Additional $\mathrm{Ga}_{2} \mathrm{O}_{3}$ phase was formed almost at all substitutional levels. Interestingly, the XRD patterns of the samples with $\mathrm{x}=1-2$ annealed at $1000{ }^{\circ} \mathrm{C}$ showed a minor amount of $\mathrm{Ga}_{2} \mathrm{O}_{3}$ crystalline phase (PDF 41-1103) (see Figure 1b), which was not observed in the samples heated at $700{ }^{\circ} \mathrm{C}$.

The cubic cell parameters were calculated for all Ga-doped $\mathrm{CoCr}_{2-\mathrm{x}} \mathrm{Ga}_{\mathrm{x}} \mathrm{O}_{4}$ samples. It is interesting to note that the cell parameter $a=8.4582(3) \AA$ determined for the $\mathrm{CoCr}_{2} \mathrm{O}_{4}$ was very similar to the cell parameter of the gallium-substituted samples. Thus, with increasing $\mathrm{Ga}^{3+}$ amount in the spinel structure, no monotonical shift of the diffraction peaks to higher or lower $2 \theta$ values were observed. This is not surprising, since the ionic radii of $\mathrm{Cr}^{3+}$ and $\mathrm{Ga}^{3+}$ ions in VI-fold coordination are almost identical ( $0.615 \AA$ for $\mathrm{Cr}^{3+}$ and $0.620 \AA$ for $\mathrm{Ga}^{3+}$ ) [25]. The estimated crystallite size of the spinel phase for all compositions ranged from 11.4 to $32.6 \mathrm{~nm}$ and from 46.6 to $54.4 \mathrm{~nm}$ for the samples obtained at 700 and $1000{ }^{\circ} \mathrm{C}$, respectively. The crystallite size decreased linearly with the increase of substitution level (see Table 1). 

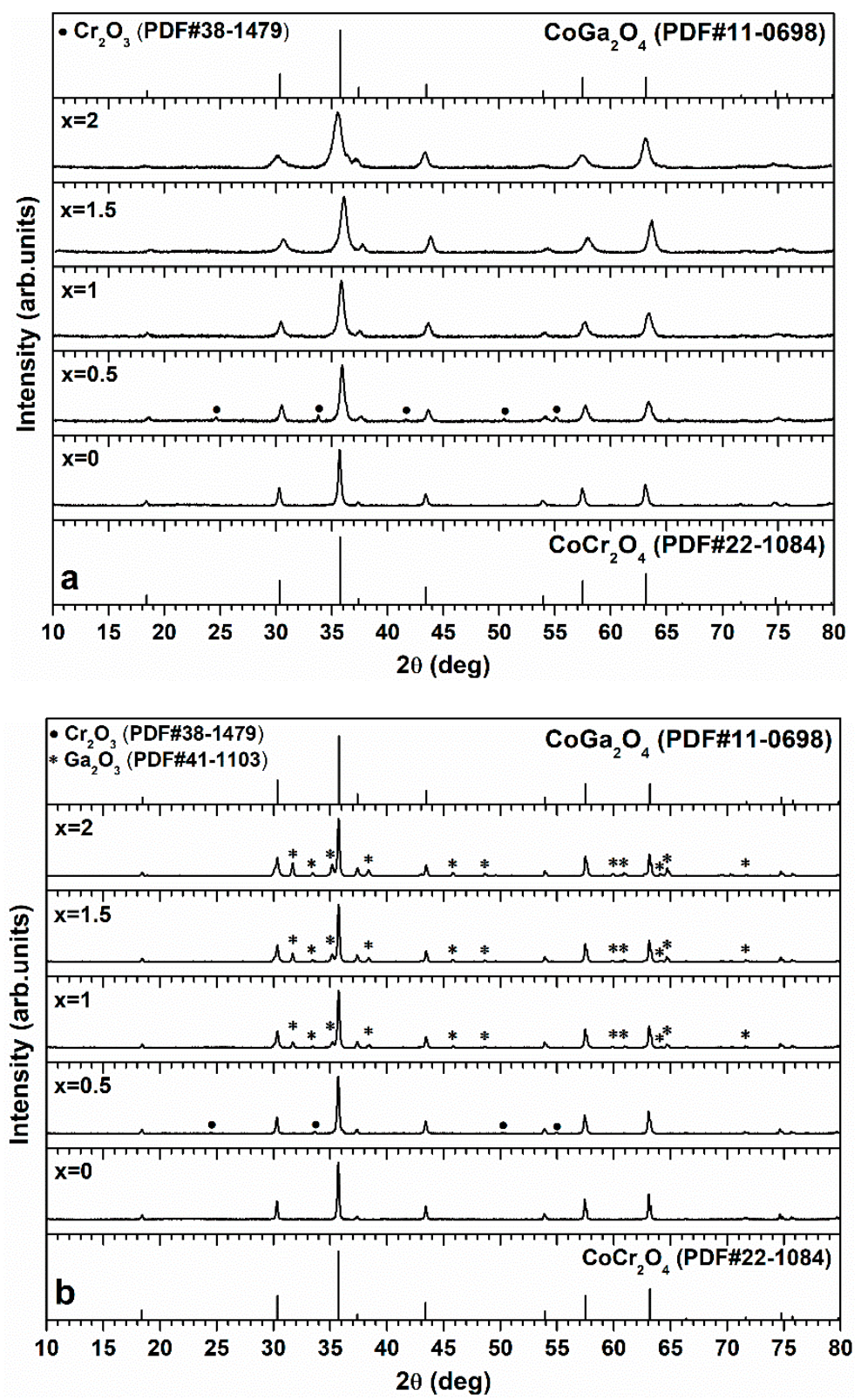

Figure 1. XRD patterns of $\mathrm{CoCr}_{2-\mathrm{x}} \mathrm{Ga}_{\mathrm{x}} \mathrm{O}_{4}$ powders $(\mathrm{x}=0-2)$ calcined at $700{ }^{\circ} \mathrm{C}(\mathbf{a})$ and annealed at $1000{ }^{\circ} \mathrm{C}(\mathbf{b})$.

Table 1. The estimated crystallite size of the $\mathrm{CoCr}_{2-\mathrm{x}} \mathrm{Ga}_{\mathrm{x}} \mathrm{O}_{4}$ powders synthesized at different temperatures.

\begin{tabular}{ccc}
\hline \multirow{2}{*}{$\mathrm{CoCr}_{2-\mathbf{x}} \mathrm{Ga}_{\mathbf{x}} \mathrm{O}_{\mathbf{4}}$ Sample } & \multicolumn{2}{c}{ Crystallite Size, $\mathbf{n m}$} \\
\cline { 2 - 3 } & $\mathbf{7 0 0}{ }^{\circ} \mathbf{C}$ & $\mathbf{1 0 0 0}{ }^{\circ} \mathbf{C}$ \\
\hline $\mathrm{x}=0$ & $32.6 \pm 0.5$ & $54.4 \pm 0.7$ \\
\hline $\mathrm{x}=0.5$ & $27.9 \pm 0.6$ & $51.9 \pm 0.5$ \\
\hline $\mathrm{x}=1.0$ & $22.4 \pm 0.4$ & $49.5 \pm 0.5$ \\
\hline $\mathrm{x}=1.5$ & $16.8 \pm 0.5$ & $48.0 \pm 0.6$ \\
\hline $\mathrm{x}=2.0$ & $11.4 \pm .0 .3$ & $46.6 \pm 0.7$ \\
\hline
\end{tabular}


To confirm the chemical composition of the synthesized samples, the elemental analysis using ICP-OES was performed. The results of the analysis are summarized in Table 2. Since Co was not changed in the synthesized series, the molar ratio of the elements was normalized by the concentration of Co. It is seen that the determined ratio is very close to the nominal values for all samples, which indicates that the suggested synthesis approach is suitable for the preparation of $\mathrm{CoCr}_{2-x} \mathrm{Ga}_{\mathrm{x}} \mathrm{O}_{4}$ powders with the controllable chemical composition of the final products.

Table 2. The results of the elemental analysis of $\mathrm{CoCr}_{2-x} \mathrm{Ga}_{x} \mathrm{O}_{4}$ powders by ICP-OES.

\begin{tabular}{cccc}
\hline $\mathrm{CoCr}_{2-\mathbf{x}} \mathrm{Ga}_{\mathbf{x}} \mathbf{O}_{\mathbf{4}}$ Sample & $\mathbf{n}(\mathrm{Co})$ & $\mathbf{n}(\mathrm{Cr})$ & $\mathbf{n}(\mathrm{Ga})$ \\
\hline $\mathrm{x}=0$ & 1 & 2.01 & - \\
\hline $\mathrm{x}=0.5$ & 1 & 1.48 & 0.510 \\
\hline $\mathrm{x}=1.0$ & 1 & 1.02 & 1.03 \\
\hline $\mathrm{x}=1.5$ & 1 & 0.491 & 1.52 \\
\hline $\mathrm{x}=2.0$ & 1 & - & 2.03 \\
\hline
\end{tabular}

The SEM micrographs of selected pigment samples ( $x=0.5$ and 2$)$ obtained at different heating temperatures are given in Figure 2. At the low heating temperature, the surface of synthesized pigments is composed of irregularly shaped particles which are highly agglomerated independently of the substitution level. The powders with the lowest substitution ratio (Figure 2a) are composed of particles with an irregular shape. The particles of the sample annealed at $1000{ }^{\circ} \mathrm{C}$ with the highest substitution ratio (Figure 2d) are needle-like plates. Nevertheless, the agglomeration of the particles is very high and no separate particles could be clearly distinguished.
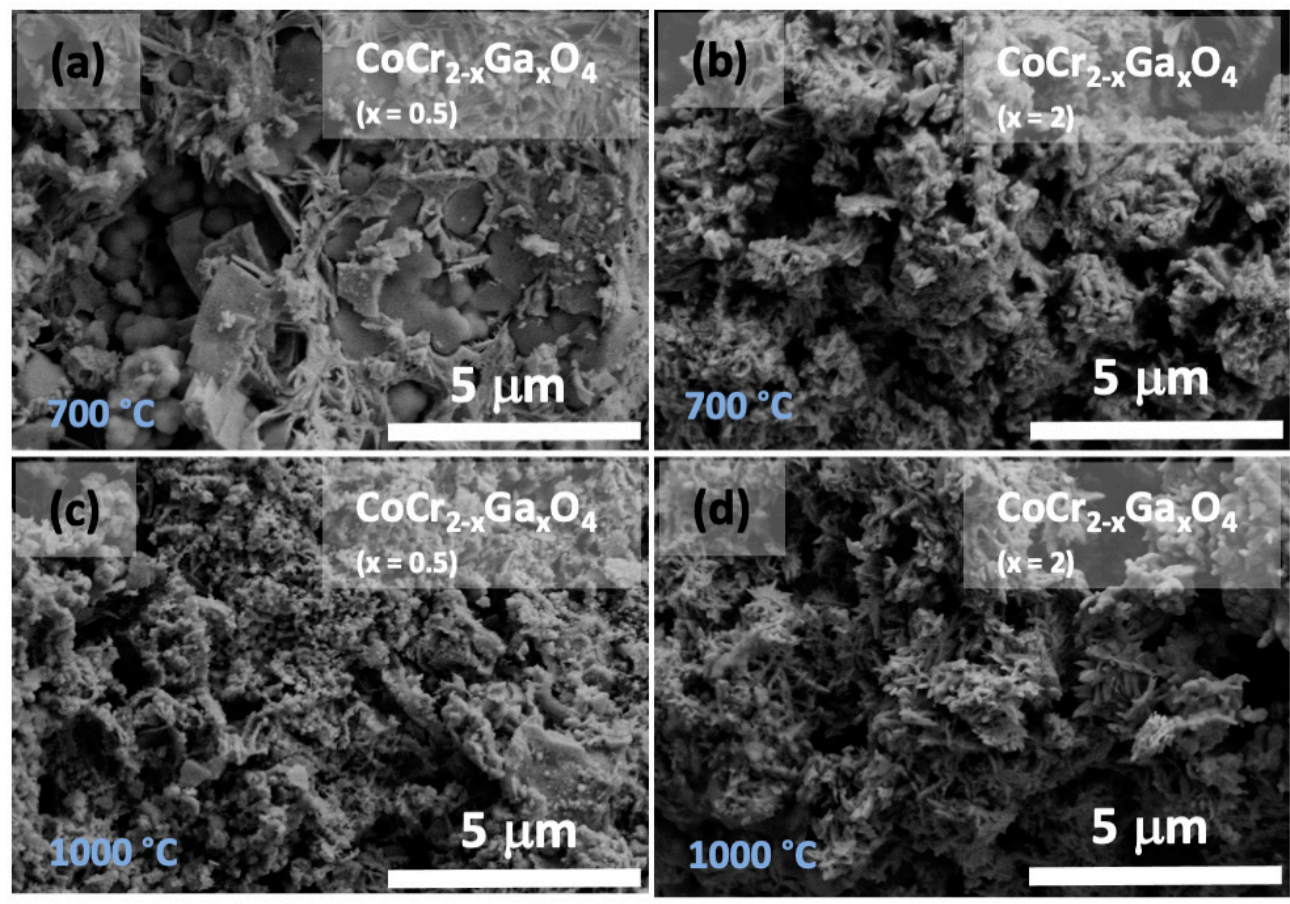

Figure 2. SEM micrographs of sol-gel derived $\mathrm{CoCr}_{2-x} \mathrm{Ga}_{x} \mathrm{O}_{4}$ pigments, when $\mathrm{x}=0.5(\mathbf{a}, \mathrm{c})$ and $\mathrm{x}=2(\mathbf{b}, \mathbf{d})$, obtained at $700{ }^{\circ} \mathrm{C}(\mathbf{a}, \mathbf{b})$ and $1000^{\circ} \mathrm{C}(\mathbf{c}, \mathbf{d})$.

The representative SEM micrograph and a digital picture of optical microscopy of the ceramic glaze obtained using sol-gel derived fully substituted $\mathrm{CoGa}_{2} \mathrm{O}_{4}$ pigment are presented in Figure 3. SEM investigation revealed good dispersion of the pigments over ceramic tiles. However, the separate 
particles are visible in the $\mathrm{CoGa}_{2} \mathrm{O}_{4}$ glaze (Figure 3a). Optical microscopy confirmed the presence of pigment particles on the surface and negligible formation of gas bubbles. No cracks, caves, or other physical defects could be observed on the surface of ceramic glazes, notwithstanding the mentioned bubbles and separate particles.
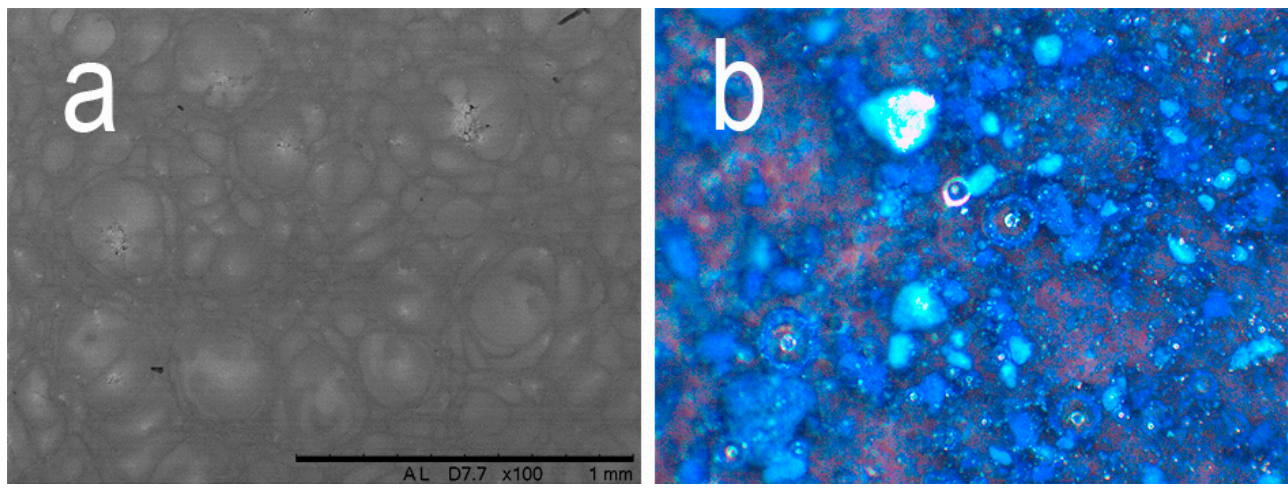

Figure 3. Images of the glaze prepared using $\mathrm{CoGa}_{2} \mathrm{O}_{4}$ obtained by SEM (X 100) (a) and optical microscopy (X 60) (b).

The colorimetric parameters of the pigments obtained at $1000{ }^{\circ} \mathrm{C}$ and corresponding glazes are summarised in Table 3. As it was presumed, the most divergent results of the CIELab measurements are of the pigment and glaze samples when $x=0.5$. The impurity of $\mathrm{Cr}_{2} \mathrm{O}_{3}$ gives a greener hue to the mentioned specimens, reasoning the most negative values of parameter $\mathrm{a}^{*}$, comparing to the results of other samples with $x=1-2$. The general tendency of increase of lightness parameter $L^{*}$ for the pigments and decrease for the glazes with an increase of substitution ratio is well observed. Moreover, for the pigments the values of parameter $b^{*}$ are increasingly negative with the increase of gallium concentration, implying the enhancement of blue hue. On the contrary, for the glazes the values of parameter $\mathrm{a}^{*}$ convert into positive values, meaning the enhancement of red hue. Corresponding to the CIELab results, the pigments give diversity in colors from bluish-green to light blue (Figure 4).

Table 3. CIELab colorimetric parameters of the $\mathrm{CoCr}_{2-\mathrm{x}} \mathrm{Ga}_{\mathrm{x}} \mathrm{O}_{4}$ pigments, obtained at $1000{ }^{\circ} \mathrm{C}$, and corresponding glazes.

\begin{tabular}{ccccccc}
\hline \multirow{2}{*}{ Amount of Ga (x) } & \multicolumn{3}{c}{ Pigment } & \multicolumn{3}{c}{ Glaze } \\
\cline { 2 - 7 } & $\boldsymbol{L}^{*}$ & $\boldsymbol{a}^{*}$ & $\boldsymbol{b}^{*}$ & $\boldsymbol{L}^{*}$ & $\boldsymbol{a}^{*}$ & $\boldsymbol{b}^{*}$ \\
\hline 0 & 47.69 & -8.31 & -3.89 & 33.47 & -10.92 & -10.36 \\
0.5 & 50.25 & -12.39 & -7.56 & 30.86 & -7.59 & -4.41 \\
1 & 48.48 & -8.49 & -5.60 & 31.53 & -4.01 & -4.16 \\
1.5 & 52.48 & -11.83 & -8.36 & 30.74 & -4.32 & -6.84 \\
2 & 54.44 & -9.48 & -14.07 & 27.69 & 3.67 & -9.35 \\
\hline
\end{tabular}




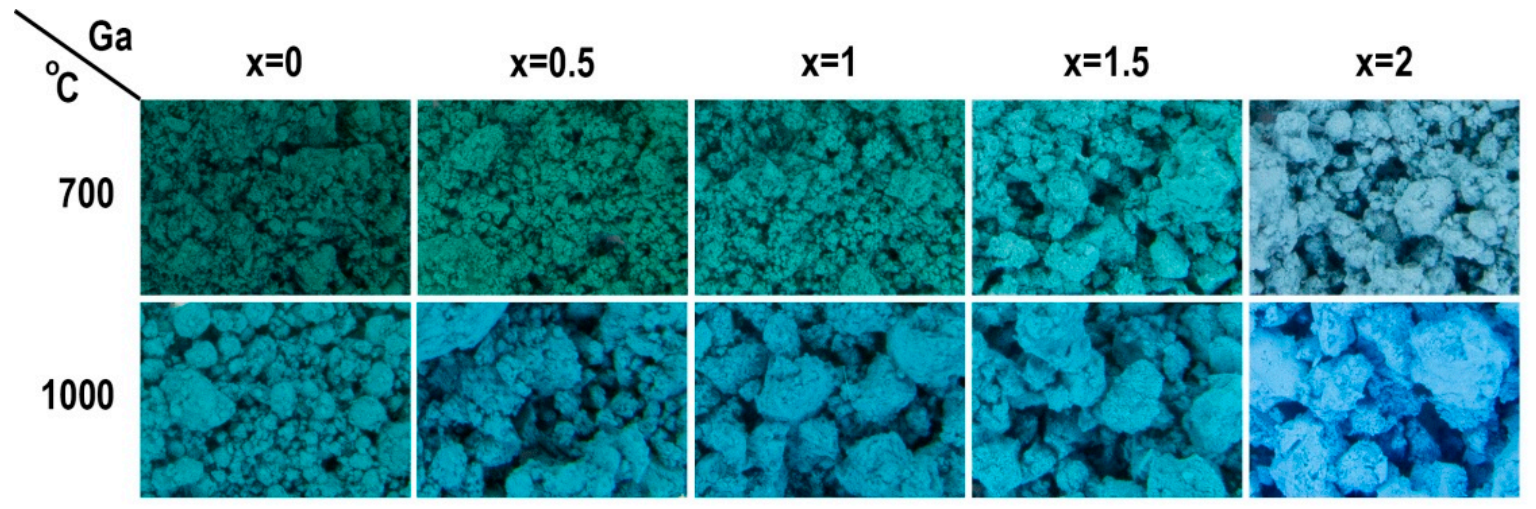

Figure 4. Digital photographs of Ga-doped cobalt chromite pigments obtained at different heating temperatures.

The pigments annealed at $1000{ }^{\circ} \mathrm{C}$ possess brighter colors. The confirmation of the CIELab results of ceramic glazes is given in Figure 5. The outstanding glazes are obtained with different substitutional levels of gallium. As was expected, the glaze with $\mathrm{CoCr}_{1.5} \mathrm{Ga}_{0.5} \mathrm{O}_{4}$ pigment possesses a green hue due to the additional chromium(III) oxide phase. However, the most unexpected results, concerning the colors of the pigments, were with the fully substituted pigmented glaze, which turned out to be violetish blue.

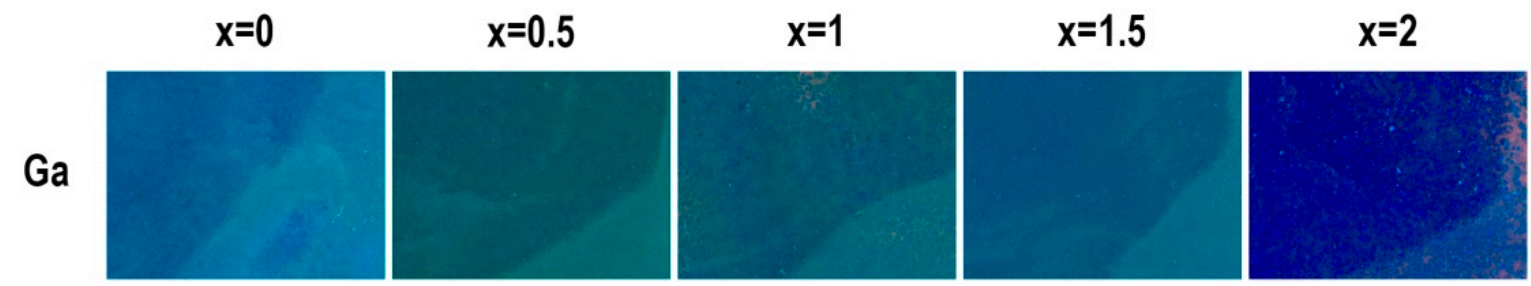

Figure 5. Digital photographs of the ceramic glazes prepared with Ga-doped pigments.

\section{Conclusions}

The attempts to synthesize the single-phase $\mathrm{CoCr}_{2-x} \mathrm{Ga}_{x} \mathrm{O}_{4}$ samples using sol-gel method were done in this study. The main crystalline phase of the synthesis products obtained at $700{ }^{\circ} \mathrm{C}$ was a solid solution of cubic $\mathrm{CoCr}_{2} \mathrm{O}_{4}$ and $\mathrm{CoGa}_{2} \mathrm{O}_{4}$ spinels. However, an additional $\mathrm{Cr}_{2} \mathrm{O}_{3}$ phase was observed for the sample with $x=0.5$. Phase composition analysis revealed that chromium substitution by gallium was not successful at a higher temperature either. A minor amount of $\mathrm{Ga}_{2} \mathrm{O}_{3}$ crystalline phase was detected in XRD patterns of the samples with $x=1-2$ annealed at $1000{ }^{\circ} \mathrm{C}$. SEM analysis revealed that the agglomeration of the particles is very high and no separate particles could be clearly distinguished. SEM micrographs and optical microscopy investigation revealed well dispersion of the pigments within ceramic glazes prepared using $\mathrm{CoCr}_{2-x} \mathrm{Ga}_{x} \mathrm{O}_{4}$ pigments. The formation of high-quality glazes was confirmed. However, the colors of obtained $\mathrm{CoCr}_{2-x} \mathrm{Ga}_{x} \mathrm{O}_{4}$ pigments and their corresponding ceramic glazes were unexpected. The substitution of $\mathrm{Cr}^{3+}$ by Ga ${ }^{3+}$ ion led to the gradual light blueness of the pigment. The impurity of $\mathrm{Cr}_{2} \mathrm{O}_{3}$ in the sample with the lowest substitution ratio gave the green hue to both the pigment and the corresponding ceramic glaze. Surprisingly, the ceramic glaze prepared using fully substituted $\mathrm{CoGa}_{2} \mathrm{O}_{4}$ pigment turned out to possess violetish blue color.

Author Contributions: Conceptualization, E.G. (Egle Grazenaite) and A.K.; methodology, E.G. (Egle Grazenaite) and E.G. (Edita Garskaite); formal analysis, E.G. (Egle Grazenaite), Z.S., E.R.-S., A.Z., and A.K.; investigation, E.G. (Egle Grazenaite), Z.S., E.R.-S., and A.Z.; resources, E.G. (Edita Garskaite), A.K.; writing-original draft preparation, E.G. (Egle Grazenaite); writing-review and editing, A.K.; supervision, A.K.; funding acquisition, E.G. (Edita Garskaite), A.K. All authors have read and agreed to the published version of the manuscript. 
Funding: The work has been partially supported by the Swedish Research Council for Environment, Agricultural Sciences and Spatial Planning (FORMAS) Project "Utilization of solid inorganic waste from the aquaculture industry as wood reinforcement material for flame retardancy" (grant no. 2018-01198).

Acknowledgments: Authors would like to thank Gediminas Kreiza for their technical assistance and helpful discussions.

Conflicts of Interest: The authors declare no conflict of interest.

\section{References}

1. Lorenzi, G.; Baldi, G.; Di Benedetto, F.; Faso, V.; Lattanzi, P.; Romanelli, M. Spectroscopic study of a Ni-bearing gahnite pigment. J. Eur. Ceram. Soc. 2006, 26, 317-321. [CrossRef]

2. DeSouza, L.; Zamian, J.; Filho, G.N.D.R.; Soledade, L.E.; DosSantos, I.; Souza, A.; Scheller, T.; Angélica, R.S.; Dacosta, C. Blue pigments based on $\mathrm{Co}_{\mathrm{x}} \mathrm{Zn}_{1-\mathrm{x}} \mathrm{Al}_{2} \mathrm{O}_{4}$ spinels synthesized by the polymeric precursor method. Dye. Pigment. 2009, 81, 187-192. [CrossRef]

3. Cui, H.; Zayat, M.; Levy, D. Sol-Gel Synthesis of Nanoscaled Spinels Using Propylene Oxide as a Gelation Agent. J. Sol-Gel Sci. Technol. 2005, 35, 175-181. [CrossRef]

4. Jasaitis, D.; Beganskiene, D.; Senvaitiene, J.; Kareiva, A.; Ramanauskas, R.; Juskenas, R.; Selskis, A. Sol-gel synthesis and characterization of cobalt chromium spinel CoCr2O4. Chemija 2011, 22, 125-130.

5. Hedayati, H.; Alvani, A.A.S.; Sameie, H.; Salimi, R.; Moosakhani, S.; Tabatabaee, F.; Zarandi, A.A. Synthesis and characterization of $\mathrm{Co}_{1-x} \mathrm{Zn}_{\mathrm{x}} \mathrm{Cr}_{2-y} \mathrm{Al}_{\mathrm{y}} \mathrm{O}_{4}$ as a near-infrared reflective color tunable nano-pigment. Dye. Pigment. 2015, 113, 588-595. [CrossRef]

6. Hu, D.-S.; Han, A.-J.; Ye, M.; Chen, H.-H.; Zhang, W. 2-xAlxO4 by Low-temperature Combustion Synthesis. J. Inorg. Mater. 2011, 26, 285-289. [CrossRef]

7. Chamyani, S.; Salehirad, A.; Oroujzadeh, N.; Fateh, D.S. Effect of fuel type on structural and physicochemical properties of solution combustion synthesized $\mathrm{CoCr}_{2} \mathrm{O}_{4}$ ceramic pigment nanoparticles. Ceram. Int. 2018, 44, 7754-7760. [CrossRef]

8. Miranda, E.A.C.; Sepúlveda, A.A.L.; Carvajal, J.F.M.; Gil, S.V.; Baena, O.J.R. Green inorganic pigment production with spinel structureCoCr $\mathrm{O}_{4}$ by solution combustion synthesis. TECCIENCIA 2019, 14, 41-51. [CrossRef]

9. Lei, S.-L.; Liang, G.-J.; Wang, Y.; Zhou, S.-X.; Zhang, X.; Li, S. Sol-gel combustion synthesis and characterization of $\mathrm{CoCr}_{2} \mathrm{O}_{4}$ ceramic powder used as color solar absorber pigment. Optoelectron. Lett. 2020, 16, 365-368. [CrossRef]

10. Mindru, I.; Gingasu, D.; Marinescu, G.; Patron, L.; Calderon-Moreno, J.M.; Bartha, C.; Andronescu, C.; Crişan, A. Cobalt chromite obtained by thermal decomposition of oxalate coordination compounds. Ceram. Int. 2014, 40, 15249-15258. [CrossRef]

11. Tanisan, B.; Dondi, M. Cobalt chromite nano pigments synthesis through microwave-assisted polyol route. J. Sol-Gel Sci. Technol. 2017, 83, 590-595. [CrossRef]

12. Betancur-Granados, N.; Restrepo-Baena, O.J. Flame spray pyrolysis synthesis of ceramic nanopigments $\mathrm{CoCr}_{2} \mathrm{O}_{4}$ : The effect of key variables. J. Eur. Ceram. Soc. 2017, 37, 5051-5056. [CrossRef]

13. Grazenaite, E.; Pinkas, J.; Beganskiene, A.; Kareiva, A. Sol-gel and sonochemically derived transition metal (Co, Ni, Cu, and Zn) chromites as pigments: A comparative study. Ceram. Int. 2016, 42, 9402-9412. [CrossRef]

14. Grazenaite, E.; Jasulaitiene, V.; Ramanauskas, R.; Kareiva, A. Sol-gel synthesis, characterization and application of lanthanide-doped cobalt chromites $\left(\mathrm{CoCr}_{2-\mathrm{x}} \mathrm{Ln}_{\mathrm{x}} \mathrm{O}_{4} ; \mathrm{Ln}=\mathrm{Tm}^{3+}\right.$ and $\left.\mathrm{Yb}^{3+}\right)$. J. Eur. Ceram. Soc. 2018, 38, 3361-3368. [CrossRef]

15. Omata, T.; Ueda, N.; Hikuma, N.; Ueda, K.; Mizoguchi, H.; Hashimoto, T.; Kawazoe, H. New oxide phase with wide band gap and high electroconductivity $\mathrm{CdGa}_{2} \mathrm{O}_{4}$ spinel. Appl. Phys. Lett. 1993, 62, 499-500. [CrossRef]

16. Omata, T.; Ueda, N.; Ueda, K.; Kawazoe, H. New ultraviolet-transport electroconductive oxide, $\mathrm{ZnGa}_{2} \mathrm{O}_{4}$ spinel. Appl. Phys. Lett. 1994, 64, 1077-1078. [CrossRef]

17. Mondal, A.; Manam, J. Investigations on spectroscopic properties and temperature dependent photoluminescence of $\mathrm{Cr}^{3+}$ doped $\mathrm{MgGa}_{2} \mathrm{O}_{4}$ phosphor. Mater. Res. Express 2019, 6, 095081. [CrossRef]

18. Mondal, A.; Manam, J. Structural and Luminescent Properties of $\mathrm{Si}^{4+} \mathrm{Co}$-Doped $\mathrm{MgGa}_{2} \mathrm{O}_{4}: \mathrm{Cr}^{3+} \mathrm{Near}$ Infra-Red Long Lasting Phosphor. ECS J. Solid State Sci. Technol. 2017, 6, R88-R95. [CrossRef] 
19. Biswas, S.K.; Sarkar, A.; Pathak, A.; Pramanik, P. Studies on the sensing behaviour of nanocrystalline $\mathrm{CuGa}_{2} \mathrm{O}_{4}$ towards hydrogen, liquefied petroleum gas and ammonia. Talanta 2010, 81, 1607-1612. [CrossRef]

20. Cabello, G.; Lillo-Arroyo, L.; Caro-Díaz, C.; Valenzuela-Melgarejo, F.; Fernández-Pérez, A.; Buono-Core, G.; Chornik, B. Study on the photochemical preparation of nickel gallium oxide spinel doped with $\mathrm{Eu}(\mathrm{III})$ ions from carboxylate and $\beta$-diketonate complexes and the evaluation of its optical properties. Thin Solid Films 2018, 647, 33-39. [CrossRef]

21. Galindo, R.; Llusar, M.; Tena, M.A.; Monros, G.; Badenes, J. New pink ceramic pigment based on chromium (IV)-doped lutetium gallium garnet. J. Eur. Ceram. Soc. 2007, 27, 199-205. [CrossRef]

22. Galindo, R.; Badenes, J.; Llusar, M.; Tena, M.; Ángeles; Monros, G. Synthesis and characterisation of chromium lutetium gallium garnet solid solution. Mater. Res. Bull. 2007, 42, 437-445. [CrossRef]

23. Monrós, G.; Pinto, H.; Badenes, J.; Llusar, M.; Tena, M.; Ángeles; March, J.A.B. Chromium(IV) Stabilisation in New Ceramic Matrices by Coprecipitation Method: Application as Ceramic Pigments. Z. Anorg. Allg. Chem. 2005, 631, 2131-2135. [CrossRef]

24. Tamilarasan, S.; Sarma, D.; Reddy, M.L.P.; Natarajan, S.; Gopalakrishnan, J. YGa $\mathrm{Ya}_{1-\mathrm{x}} \mathrm{Mn}_{\mathrm{x}} \mathrm{O}_{3}$ : A novel purple inorganic pigment. RSC Adv. 2013, 3, 3199-3202. [CrossRef]

25. Shannon, R.D. Revised effective ionic radii and systematic studies of interatomic distances in halides and chalcogenides. Acta Crystallogr. Sect. A 1976, 32, 751-767. [CrossRef]

Publisher's Note: MDPI stays neutral with regard to jurisdictional claims in published maps and institutional affiliations. 